Arch. histol. jap., Vol. 39, No. 1 (1976)

p. $51-66$

Department of Anatomy (Prof. T. Fujita), Niigata University School of Medicine,

Niigata, Japan

\title{
A Scanning and Transmission Electron Microscopic Study on Rat Bone Marrow Sinuses and Transmural Migration of Blood Cells
}

\author{
Masaki Muto
}

Received December 16, 1975

Summary. Bone marrow sinuses of young rats were examined under the scanning (SEM) and transmission electron microscopes (TEM).

Marrow sinus wall was composed of three layers : an inner or luminal endothelium, an outer or adventitial cell layer, and a basal lamina in between. The luminal surface of the endothelial cells was quite smooth and showed some fenestrations, which could be divided into two types according to their size. One was represented by larger fenestrations $(1-3 \mu \mathrm{m}$ in diameter) which were presumed to be formed transiently at the site of blood cell migration, while the other by small pores $(0.1 \mu \mathrm{m})$ grouped into a cribriform area. The adventitial cells showed a discontinuous layer in the TEM. Under the SEM, the discontinuity corresponded to the spaces formed between the cytoplasmic attenuations of the cells.

Blood cell migration from the extravascular hemopoietic tissue into the sinus lumen was numerously observed. The migration occurred not through an intercellular gap, but through the larger intracellular fenestration of the endothelial lining mentioned above.

A number of megakaryocytes were identified by their bulky cytoplasm in the parenchyme. Figures suggesting the sequence of platelet liberation from this cell could be demonstrated. First, the megakaryocyte extended its peripheral cytoplasmic processes into the sinus through endothelial fenestrations. The processes, being conspicuously extended, became periodically constricted. Finally, platelets were believed to be produced by separation at the constricted portions and liberated to circulation.

The occurrence of a few endothelial fenestrations apparently unassociated with blood cell migration may possibly be ascribed to detachment of a blood cells due to vascular perfusion. The functional significance of the adventitial cell was discussed in association with blood cell migration.

Since PEASE (1955) reported the ultrastructure of bone marrow in his TEM study, much data has accumulated on the two-dimensional fine architecture of bone marrow sinuses. It has been established that the sinus wall consists of three layers: endothelium, basal lamina and adventitial cell layer (WEIss, 1965; DE BRUYN et al., 1966) and that many kinds of blood cells migrate through the sinus wall (ZAMBONI and Pease, 1961; Weiss, 1961, 1965, 1970; Yoffey et al., 1965; Hudson and Yoffey, 1966; De Bruyn et al. 1966, 1971; W at anabe, 1966; Huhn 1966; Campbell, 1972; Tavassoli and CROSBY 1973). However, there are some questions remaining to be solved; 1) whether or not endothelial fenestrations, except for temporary ones for blood cell migration, are artifacts, 2) what is the three-dimensional structure of adventitial cells, and 3 ) how and where blood platelets liberate from megakaryocytes.

In the present study, scanning electron microscopy (SEM) was introduced with the hope that an "en face" view of the sinus wall components would be obtained and processes of blood cell migration and platelet liberation into circulation might be three-dimensionally visualized. As far as we know, only a few SEM studies have 
been published in this field (Trubowitz et al., 1970; MiYoshi, 1975; Irino et al., 1975) and the data obtained by SEM has not been compared with that by transmission electron microscopy (TEM). We thus attempted a combined SEM and TEM study to overcome previous difficulties in studying only two-dimensional images of the tissue.

\section{Material and Methods}

Use was made of ten albino rats of $20-30$ days of age, weighing $35-60 \mathrm{~g}$. Bone marrow in the femur and tibia was examined after perfusion fixation via the thoracic aorta. After the animals were anesthetized with an intraperitoneal injection of sodium pentobarbital, the thorax was opened and the thoracic aorta was cannulated with a polyethylene tube connected with a syringe. The tip of the tube inserted into the aorta proceeded down close to the iliac bifurcation. Perfusion was made with 80-90 $\mathrm{ml}$ Ringer solution to wash the vascular bed, and then either with a fixative of $2.5 \%$ glutaraldehyde $(0.1 \mathrm{M}$ phosphate buffer, $\mathrm{pH}$ 7.4) or with a fluid containing $1 \%$ glutaraldehyde and $1 \%$ paraformaldehyde $(0.1 \mathrm{M}$ phosphate buffer, $\mathrm{pH}$ 7.4). The right atrium was opend to drain the blood and perfusates. The fixative of $80-90 \mathrm{ml}$ was allowed to perfuse for one minute and a half, after which the hind legs were detached and the tibias and femurs were isolated. A portion of the substantia compacta was carefully nibbled away with fine bone forceps and the marrow was scooped out with fine forceps, and then plunged into the same fixative.

The samples fixed by $2.5 \%$ glutaraldehyde then were processed for SEM. They kept in the $2.5 \%$ glutaraldehyde in the same buffer for $6 \mathrm{hrs}$, transferred successively to a solution of $2 \%$ sucrose, $2 \%$ sodium glutamate and $2 \%$ glycine, to $2 \%$ tannic acid and to $2 \%$ osmium tetroxide solution according to the method of Murakami (1974). They were then washed several times in distilled water, dehydrated with a graded series of alcohol and transferred to isoamyl acetate. The specimens were freezecracked in liquid nitrogen by the method reported by TokUNAGA et al. (1974) and processed to $\mathrm{CO}_{2}$ critical point drying. Though a portion of samples was scanned without any metal coating, most of them were vacuum-evaporated with gold palladium and observed with an accelerating voltage of $10 \mathrm{kV}$ in a field emission SEM, Hitachi HFS-2.

The specimens perfused with mixture fixative of $1 \%$ glutaraldehyde and $1 \%$ paraformaldehyde were processed for TEM. They were further cut into small blocks, and immersed in the same fixative for $2 \mathrm{hrs}$ and post-fixed with $2 \%$ osmium tetroxide for $2 \mathrm{hrs}$. The specimens were dehydrated with a graded series of alcohol and propylene oxide, embedded in LUFT's epoxy resin, and cut into ultra-thin sections with glass knives in a Porter-Blum MT-1 microtome. The sections were doubly stained with uranium acetate and MiLloniG's lead acetate and examined at $75 \mathrm{kV}$ in a TEM, Hitachi HU 125. DS.

\section{Observations}

In the low power SEM and TEM views, the bone marrow could be divided into two compartments: a vascular compartment and an extravascular or myeloid tissue occupied by a great abundance of hemopoietic cells (Fig. 1, 2, 4, 5). The vascular compartment of bone marrow was composed of highly anastomosed sinuses and a central longitudinal vein. This central vessel was so large in diameter as to macro- 
scopically distinguishable. The extravascular tissues between sinuses consisted of two components: blood cells in various stages of hemopoiesis and reticular fibrils and reticular cells which extended among blood cells and provided a supporting framework to the tissue (Fig. 4).

\section{Sinus wall}

In the TEM vertical section, three layers were identified in the sinus wall of bone marrow. They were an inner layer composed of flattened endothelial cells, a discontinuous outer layer of adventitial cells (as called by WEISS, 1965) and a dispersed basal lamina between them (Fig. 5).

1. Endothelial lining cell. Under the TEM, the endothelial cell was thin and flat with a small and slight cellular bulge containing an oval nucleus. The attenuated cytoplasm varied in thickness $(0.2-2 \mu \mathrm{m})$ and was occasionally interrupted by fenestrations of different sizes. Under the SEM, these fenestrations could be classified into two types by their size: the first type was larger ones (1-3 $\mu \mathrm{m}$ in diameter) each of which was associated with a migrating blood cell as described in detail below (Fig. 7, $8,9)$, while the second was small pores $(0.1 \mu \mathrm{m})$ which were gathered numerously so as to form sieve plates (Fig. 7). Besides these there were quite few larger fenestrations $(3 \mu \mathrm{m})$ which apparently were not associated with migrating blood cells.

The junctional lines of adjacent endothelial cells were distinctly identified on the
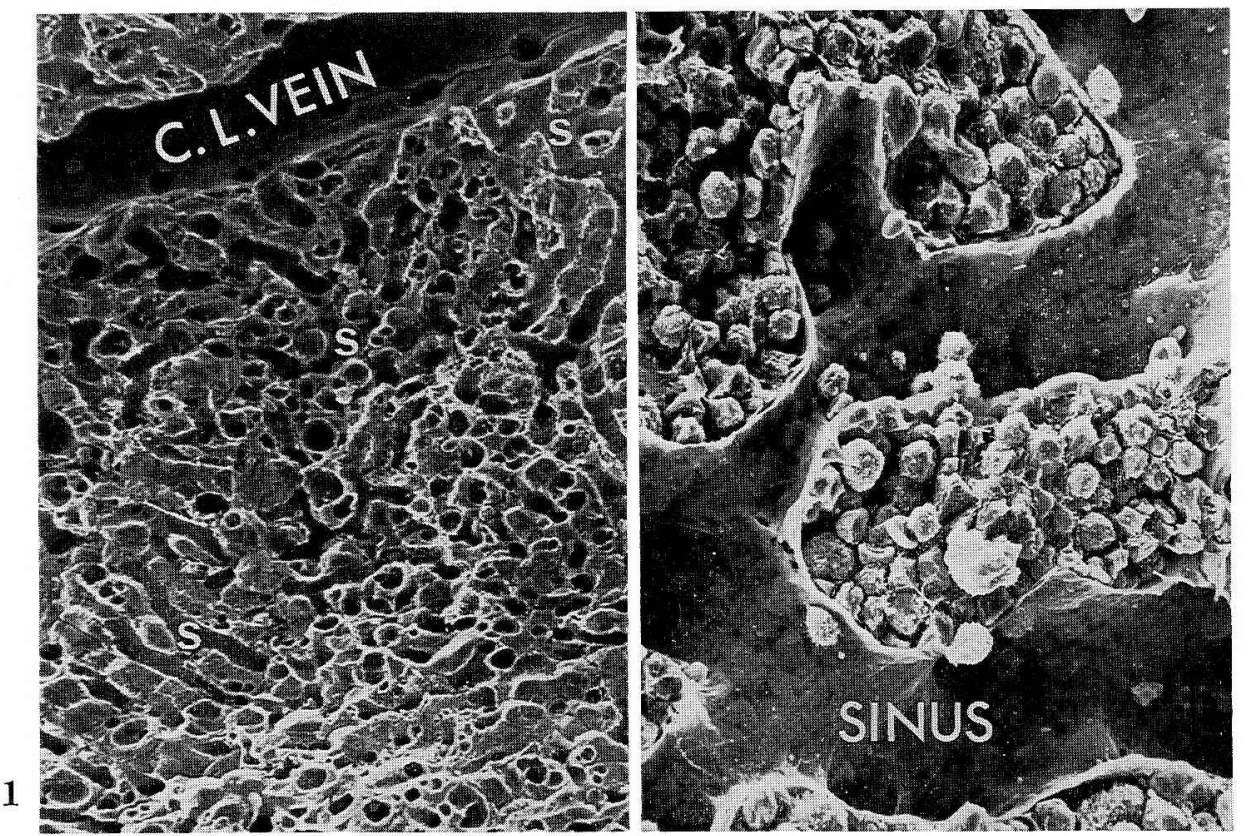

Fig. 1. A low power SEM image of bone marrow in rat tibia. The central longitudinal vein is fractured along its long axis. The vascular sinuses $(S)$ form a highly anastomosing network converging into the central vein. $\times 190$

Fig. 2. A closer view of the bone marrow without any metal coating. The sinus wall is so thin that blood cells in the extravascular hemopoietic tissue can be seen through the wall. $\times 530$ 


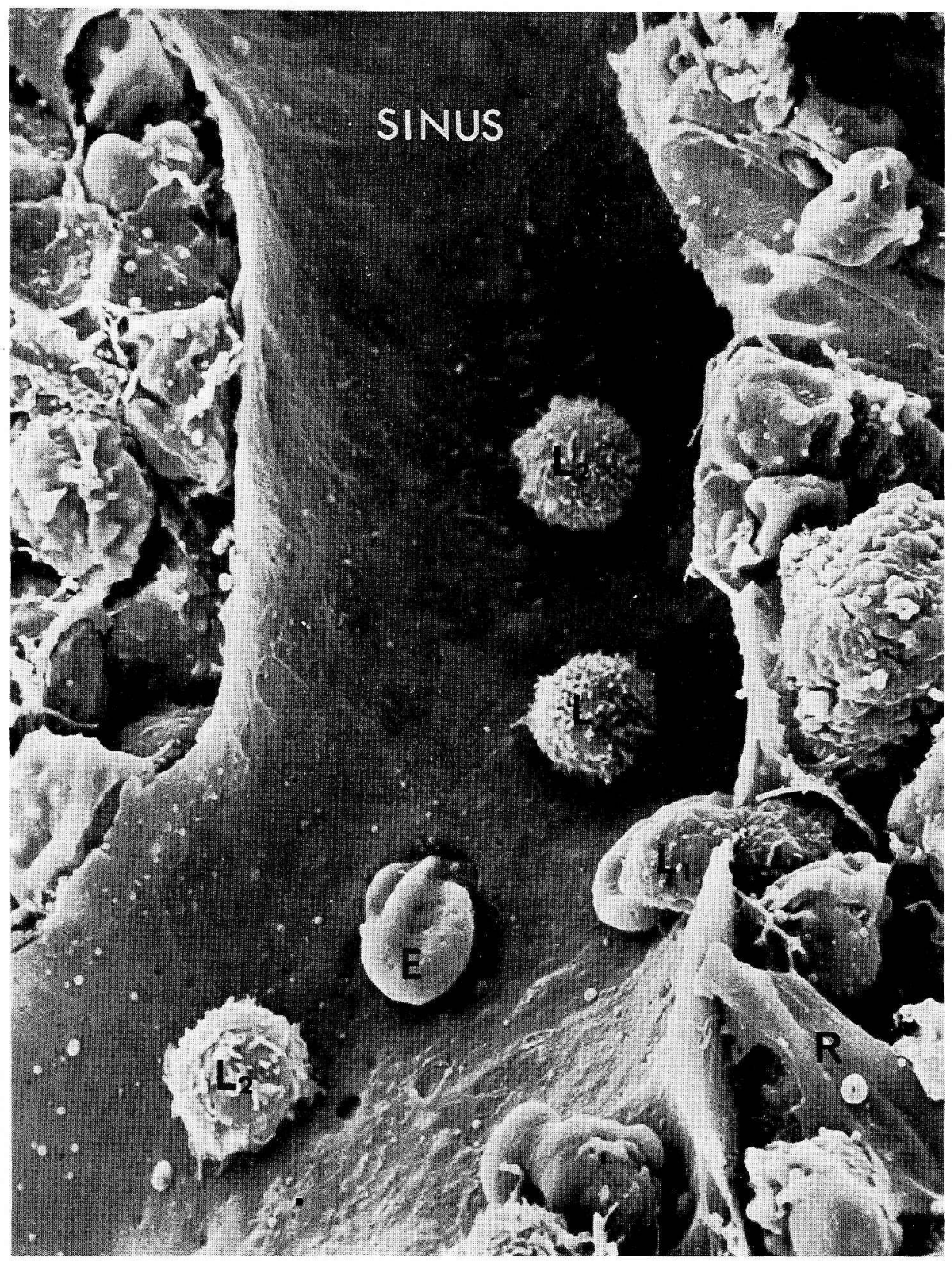

Fig. 3. Inner surface of a bone marrow sinus showing its smooth and continuous endothelium. Notice that two blood cells ( $E$ erythrocyte, $L_{1}$ leukocyte) are undergoing migration through the sinus wall. A few lymphocytes $\left(L_{2}\right)$ often remain in the sinus, resisting vascular perfusion. $R$ attenuated extension of reticulum cells. $\times 2,700$ 


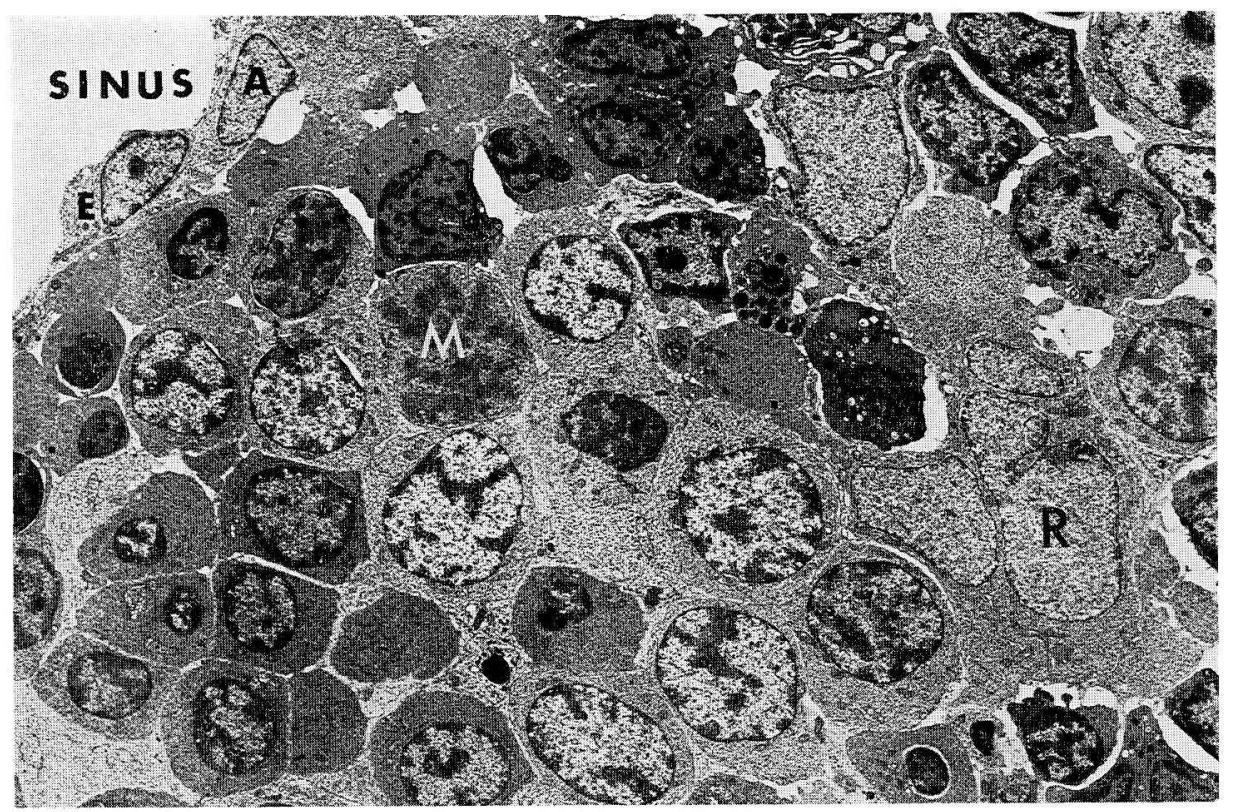

Fig. 4. A low power TEM image of the extravascular hemopoietic tissue. Reticulum cell $(R)$ with a large irregular-shaped nucleus extends its cytoplasmic processes among the forming blood cells. A mitotic figure of a blood cell is seen $(M)$. Sinus wall and its components ( $E$ endothelial lining cell, $A$ adventitial cell) are seen in the upper left part of the figure. $\quad \times 2,200$

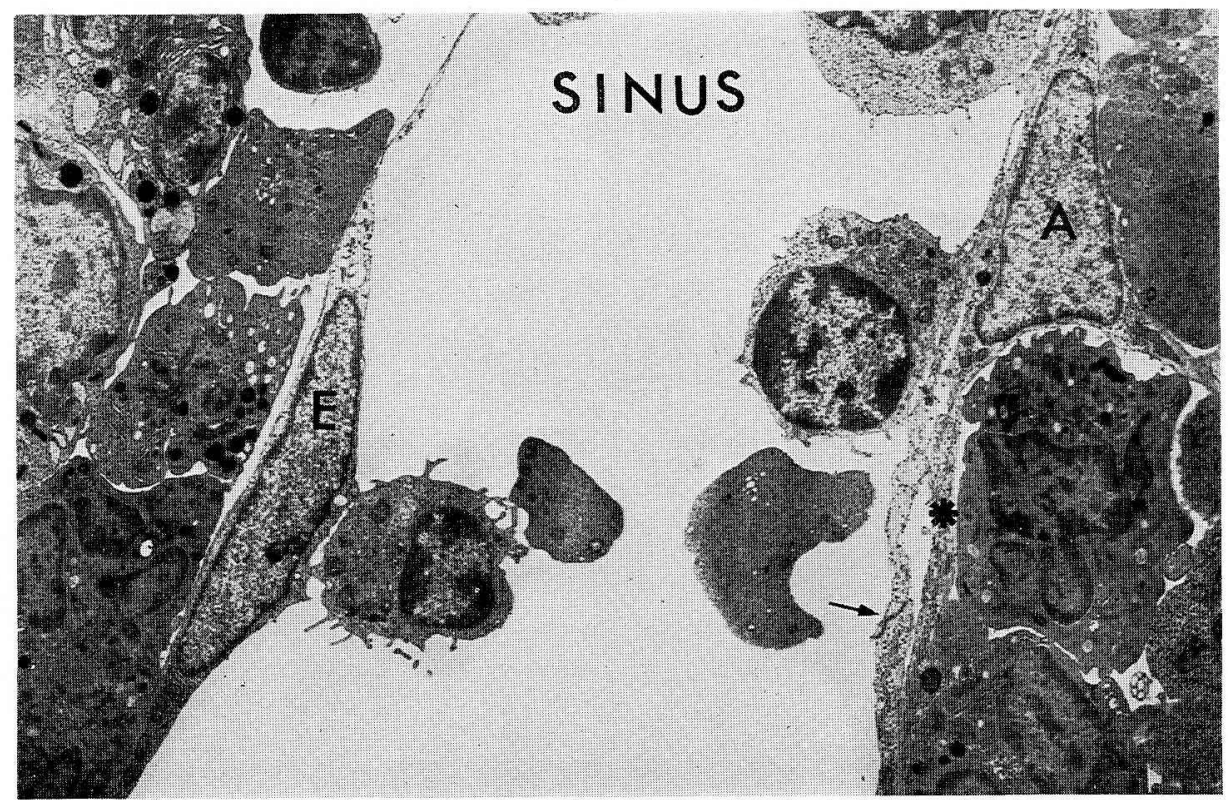

Fig. 5. A closer TEM view of the sinus wall showing an innermost endothelial lining cell $(E)$ and an adventitial cell $(A)$ located on the tissue side of the wall. An arrow indicates endothelial lining cell junction. Extensions of the adventitial cell cover the sinus wall from the side of the extrasinal tissues $(*) . \quad \times 4,200$ 


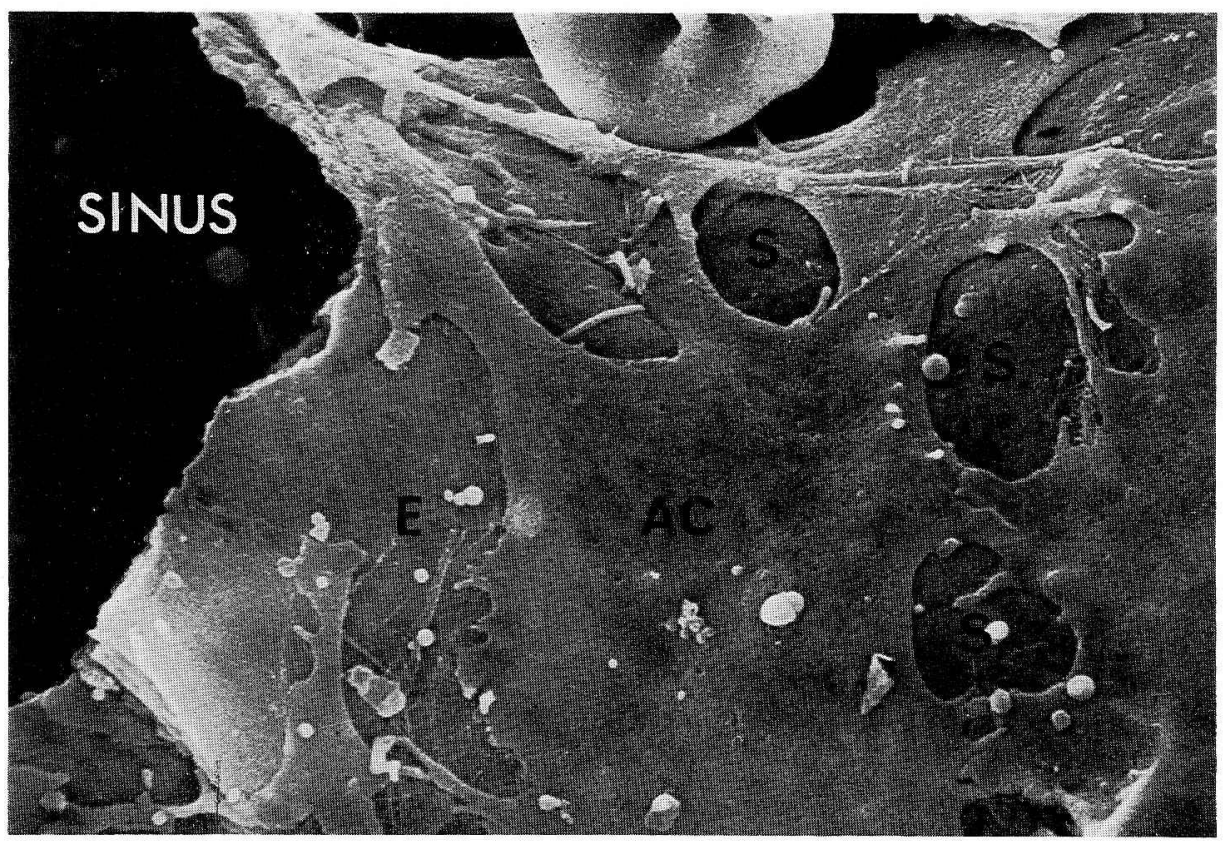

Fig. 6. Attenuated extensions of adventitial cell $(A C)$ seen from the extrasinal space. Notice spaces $(S)$ occurring between the cell extensions. Endothelial lining cell $(E) . \quad \times 5,000$

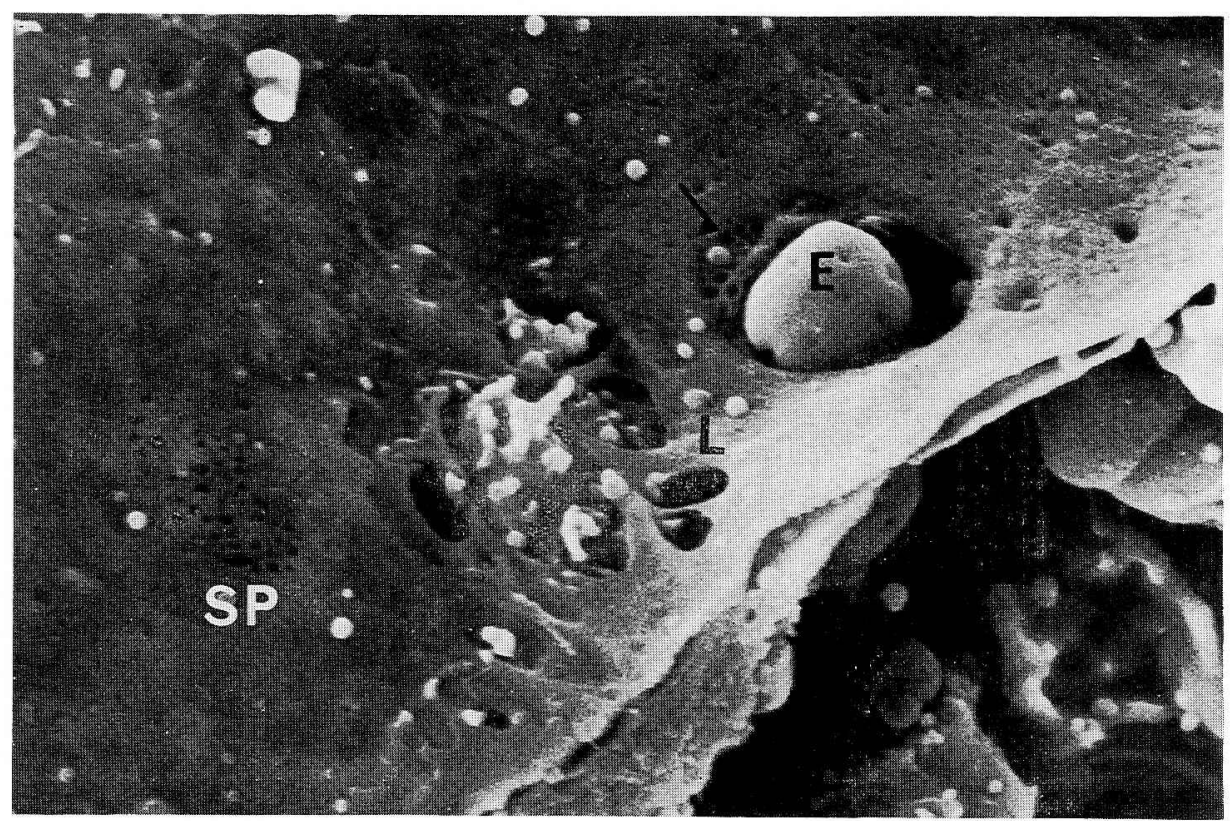

Fig. 7. Closer SEM view of fenestrations for migrating erythrocyte $(E)$ and leukocyte $(L)$ and a cribriform area of small pores $(S P)$. Notice that the small pores are associated with the large migrating fenestration (arrow). $\times 5,000$ 
luminal surface viewed under the SEM as well as in the vertical sections observed under the TEM (Fig. 5, 9, 11, 12). Under the SEM the cell border line was irregular and indented and did not diverge to form intercellular gaps. The TEM view of cross sections showed that neighboring cells attached simply with an edge to edge juxtaposition and a tight junction appeared to be less frequent than in other parts of the body.

The surface of the attenuated as well as the nucleus containing regions of the endothelium showed many pits densely disseminated (less than $0.1 \mu \mathrm{m}$ ) (Fig. 8). These structures corresponded to the vesicular invaginations which were on occasion coated with an electron dense material (Fig. 14).

2. Adventitial cell. Adventitial cells are considered to be reticulum cells which are extended vastly on the abluminal surface of the sinus and surround it almost completely. Therefore they have also been referred to as parasinusoidal reticulum cells by DE BruYn et al. (1971). The nucleus containing part of this cell was located adjacent to the sinus wall and showed a pyramidal shape whose top was protruded vertically into the myeloid tissue (Fig. 5). Slender cytoplasmic processes diverged from its tip to provide the framework of the extravascular tissues. From the base of the nucleus containing cell part, thin cytoplasmic processes extended laterally to be involved in the mural formation of the sinus. The lateral cytoplasmic processes were often of the same thickness as the lining cells and showed discontinuity of various sizes in places. The SEM view from the extrasinal side clearly demonstrated that the discontinuities as described in the previous TEM studies corresponded to the space occurring between the adjacent lateral processes (Fig. 6).

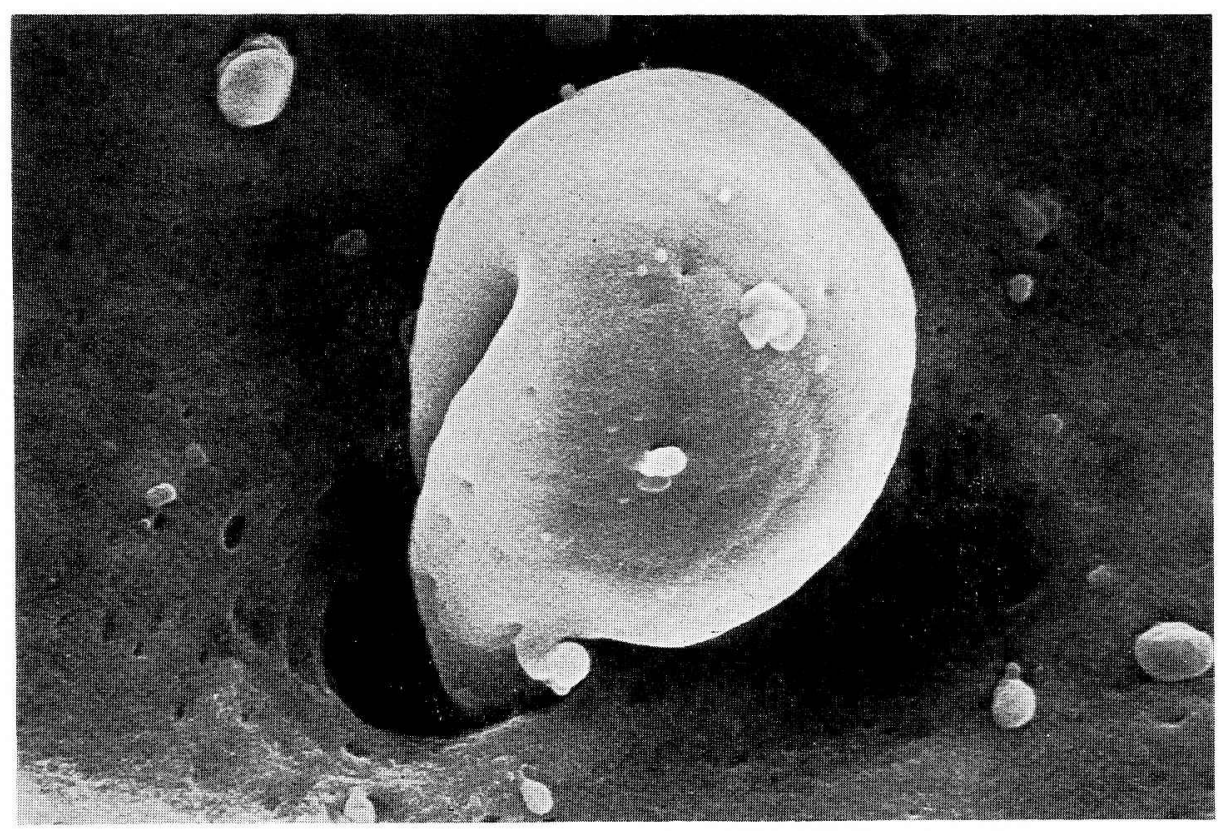

Fig. 8. An erythrocyte in passage through a fenestration of sinus wall. The endothelial cell surface shows numerous pinocy totic pits. $\times 13,000$ 


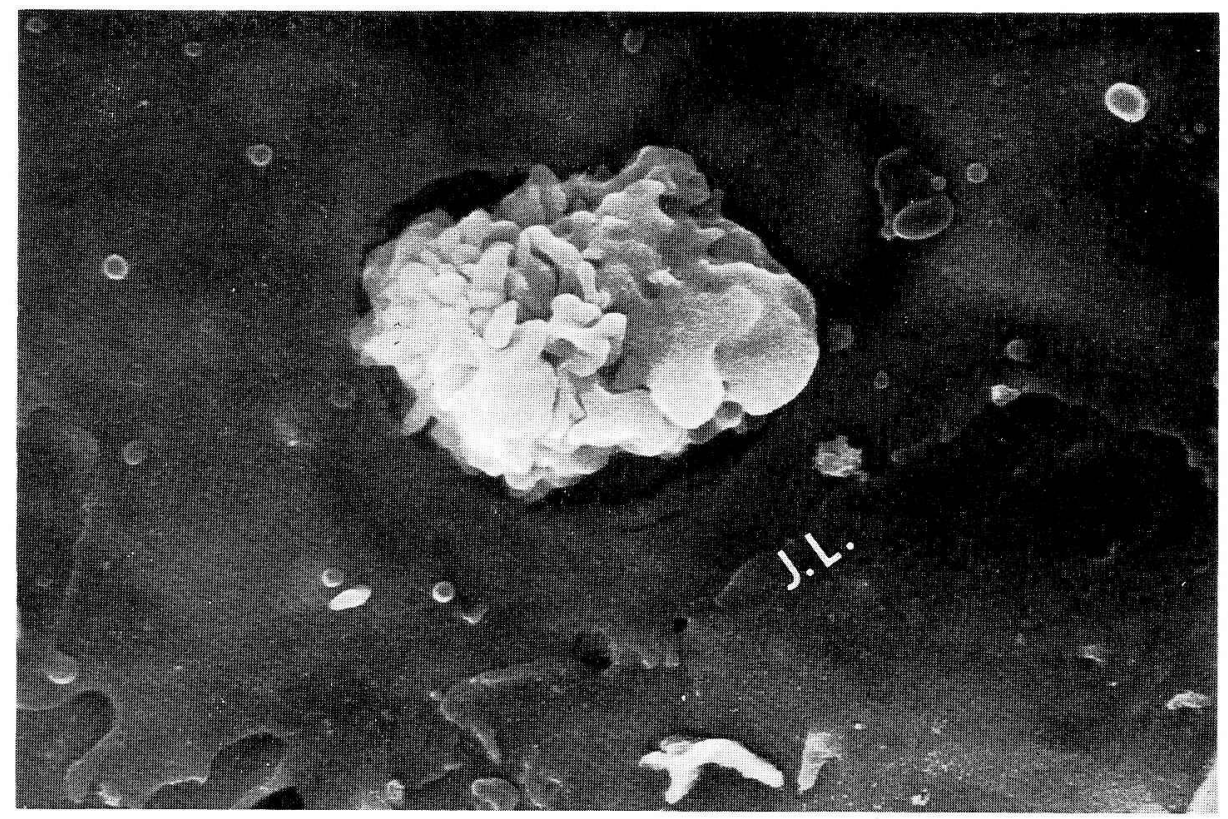

Fig. 9. A leukocyte with numerous ruffles in the process of diapedesis though the sinus wall. The endothelial cell junction $(J . L$.$) is clearly seen. \times 11,000$

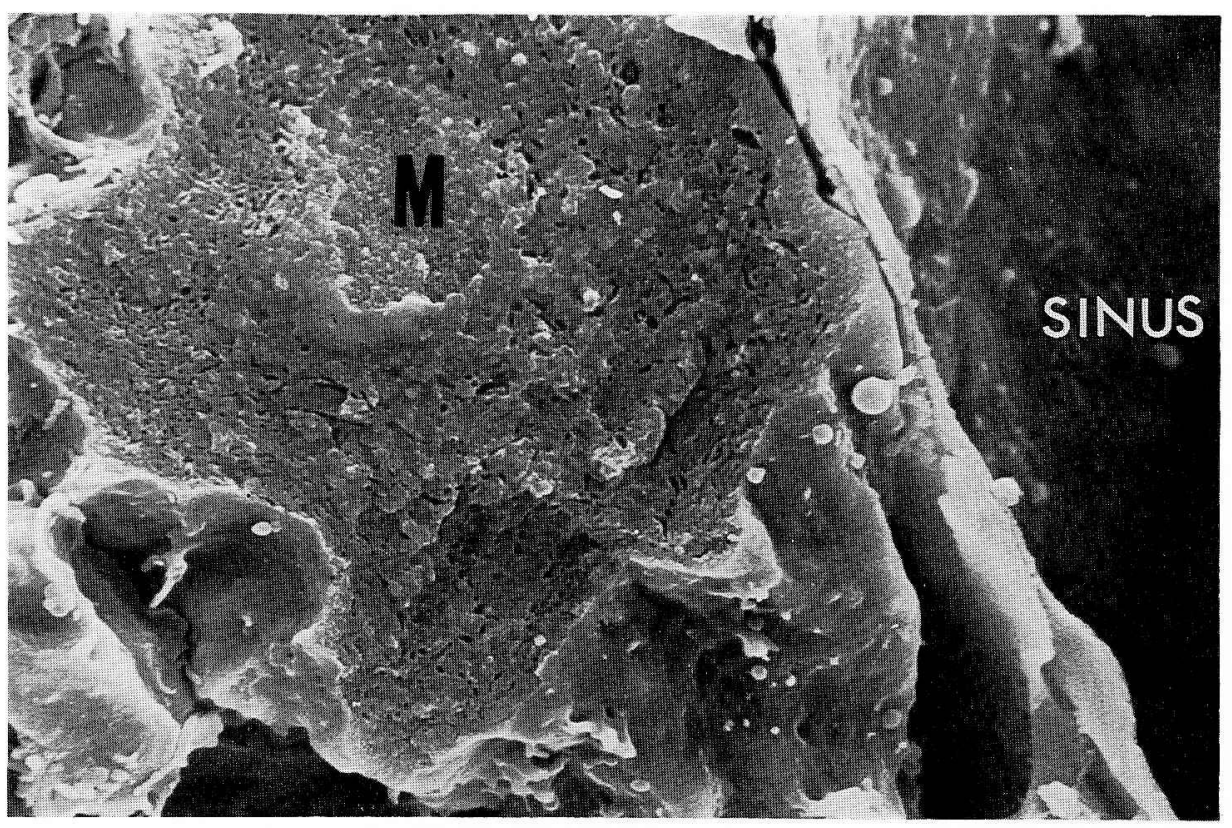

Fig. 10. Megakaryocyte $(M)$ with huge cytoplasm is fractured and the nuclear region and a number of platelet demarcating membranes can be seen. The cell is located adjacent to the sinus wall. $\times 5,000$ 


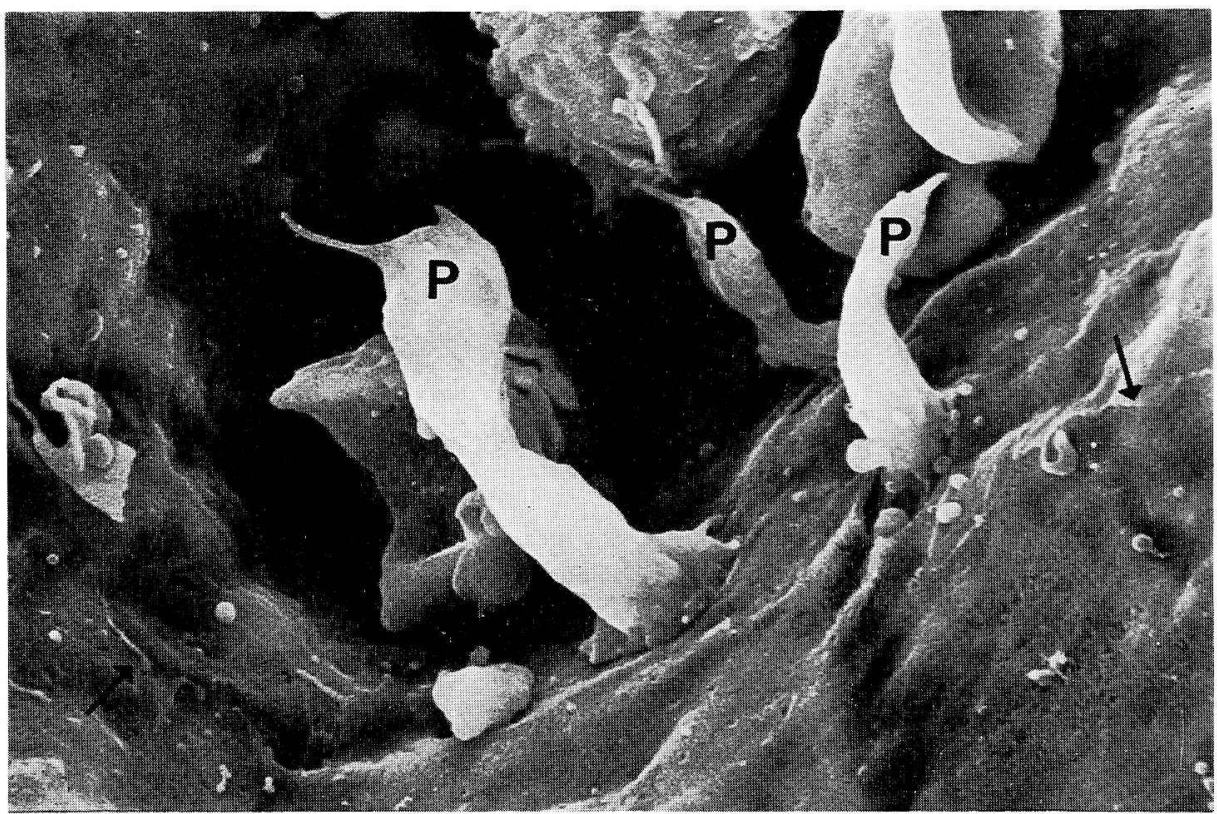

Fig. 11. High power SEM view of horn-like processes $(P)$ probably originating from a megakaryocyte. They penetrate the endothelial lining cell. Endothelial cell junction is indicated by arrows. $\times 6,000$

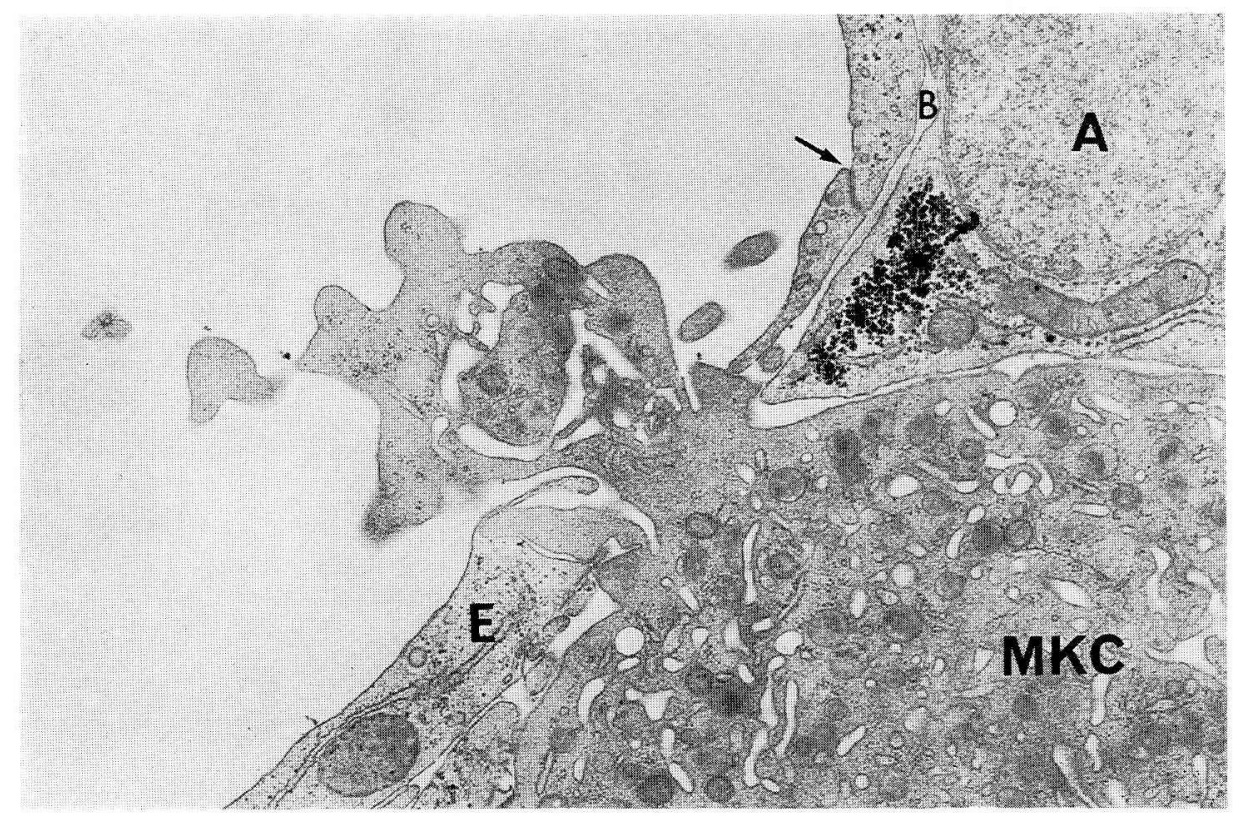

Fig. 12. TEM view of peripheral cytoplasmic process of megakaryocyte ( $M K C$ ) protruding through the fenestration of the endothelial lining cell $(E)$. The process contains platelet vesicles and demarcation membranes. A adventitial cell with aggregation of glycogen. $B$ basal lamina. Endothelial cell junction is indicated by an arrow. $\times 24,000$ 


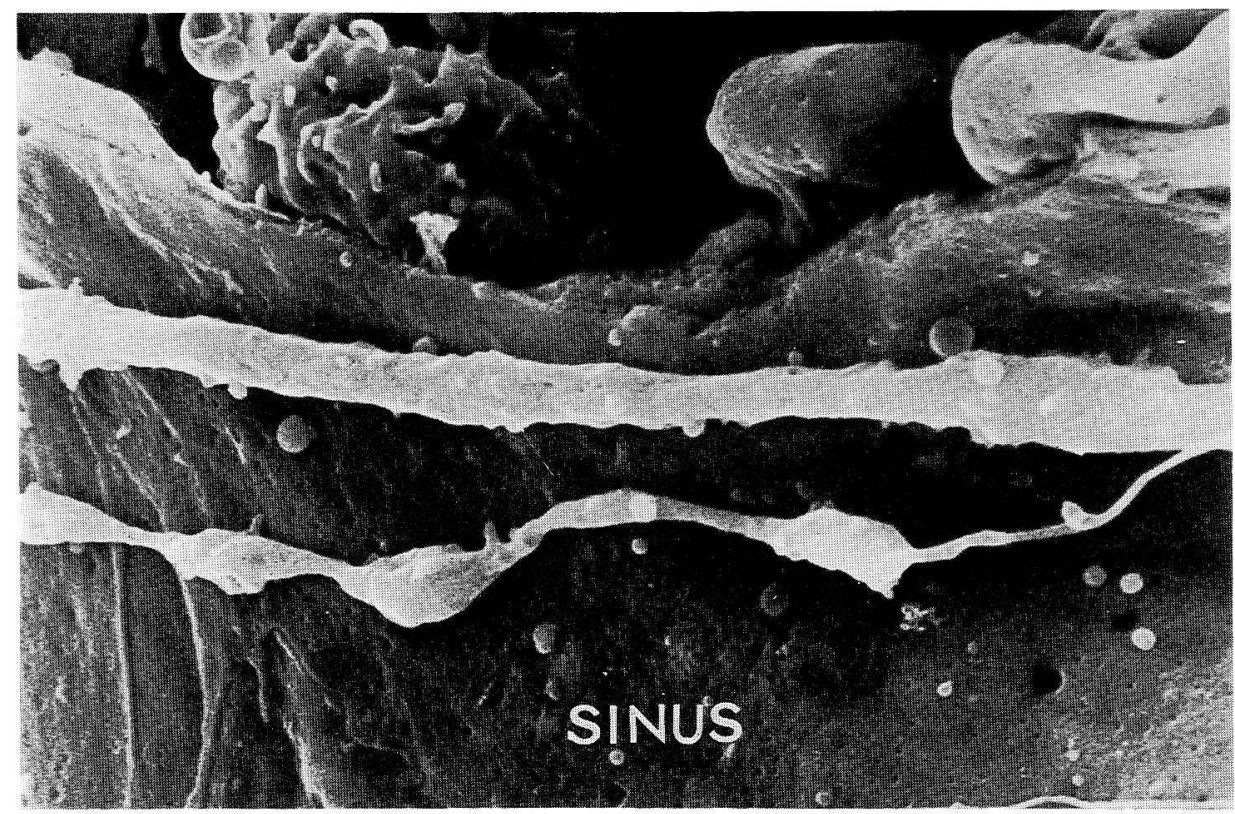

Fig. 13. High power SEM view of two processes of megakaryocyte extended far into the sinus. Notice that periodical constrictions occur in one of the processes. $\times 7,500$

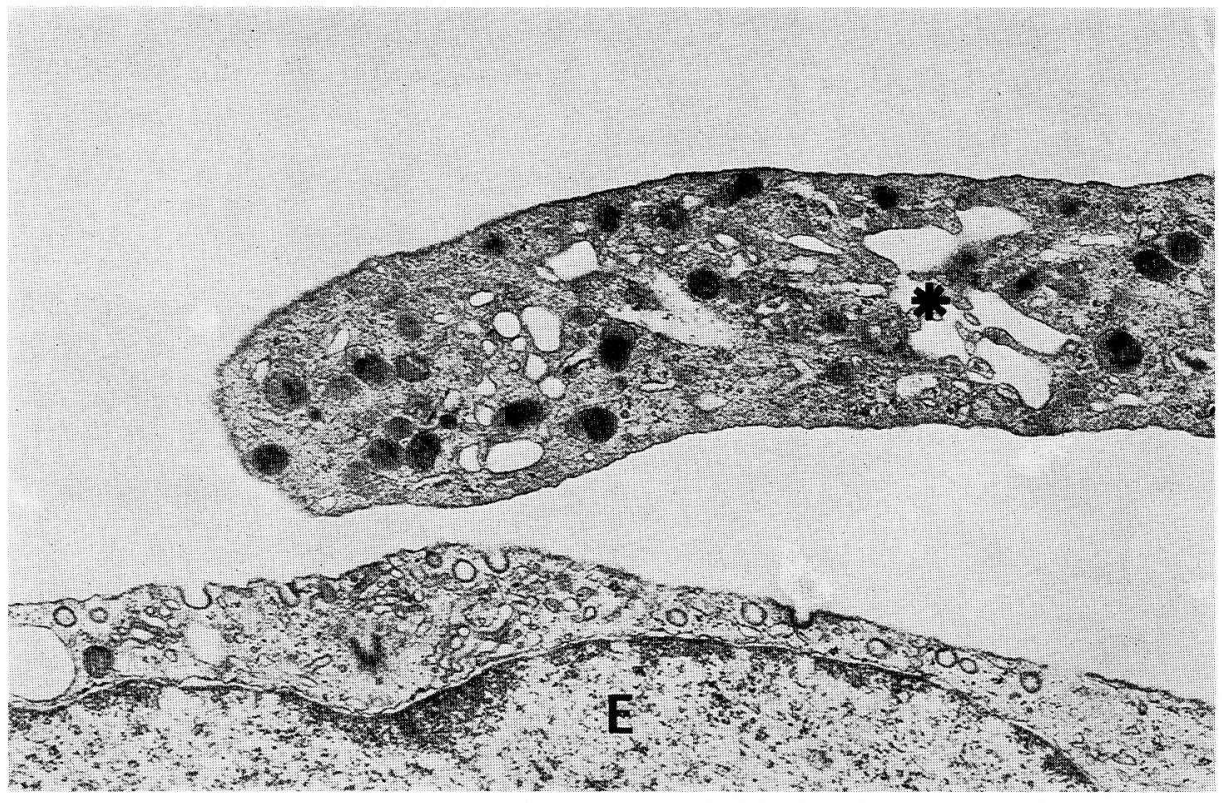

Fig. 14. TEM view of a strip-like process of megakaryocyte, containing usual organella of platelet and demarcating membrane $(*)$ in its cytoplasm. The endothelial lining cell $(E)$ shows numerous coated vesicles and invaginations at its luminal site. $\times 12,000$ 
3. Basal lamina. Basal lamina in the bone marrow sinus often was discontinuous, but in the places where a continuous adventitial cell layer occurred, the basal lamina between it and the endothelium also was continuous (Fig. 12).

\section{Entrance of blood cells into sinus}

In many sinuses the blood cells migrating through the endothelial fenestrations could be readily seen (Fig. 3, 7). Figure 8 shows an erythrocyte hanging on the sinus wall, a part of the cell being within the lumen and another part behind the sinus wall. Erythrocytes were often constricted into a dumbbell-shape at the site of the endothelial fenestration. Figure 9 shows a leukocyte with numerous microvilli and ruffles, hanging on a sinus fenestration. In the "en face" view of SEM, it is readily noticed that the pathway of the blood cells is not through gaps between adjacent lining cells, but through fenestrations occurring within the individual endothelial cells. In Figure 7, both erythrocyte and leukocyte are undergoing transmural migration. In the case of the leukocyte (left), some microvillous projections of the cell penetrate the cytoplasm of the endothelial cell, forming a lattice fenestration in the sinus wall.

\section{Megakaryocyte and platelet release}

Megakaryocyte was readily identified under the SEM by its bulky cytoplasm and its spherical shape with a relatively smooth cell surface (Fig. 10). The cell often was located close to the abluminal side of the sinus wall as shown in Figure 10. On the fracture surface of the cell one may recognize the nucleus and cytoplasm in which the platelet demarcation membrane system may be clearly identified.

Megakaryocyte frequently projects one or a few slender horn-like cytoplasmic processes into the sinus lumen through the endothelial fenestrations (Fig. 11). These cell processes contained free ribosomes, vesicles, mitochondria and platelet demarcation vesicles and membranes (Fig. 12). In some cases, the protruding processes were further elongated into the sinus and formed extremely long belts, which contained, when observed under the TEM, usual platelet organella and platelet demarcation membranes (Fig. 14). Moreover, it was noticed that such strips became constricted periodically and each segment thus formed corresponded in size and shape to an individual platelet (Fig. 13).

\section{Discussion}

\section{Endothelial cell and its fenestrations}

In spite of the numerous TEM studies on the endothelium of the bone marrow sinus, the nature of its fenestrations remains controversial. The previous authors discussed 1) the question whether or not the fenestrations unassociated with migrating blood cells are artefacts, 2) the position of fenestrations for blood cell migration and 3 ) the problem as to whether the fenestrations occur temporarily or permanently.

Concerning the first problem, many TEM authors have claimed that the fenestrations not associated with blood cells under migration are artifacts due to poor fixation and/or mechanical damage (ZAMBONI and PeAse, 1961; LindBlad and BjöRKMAN, 1964; Hunn, 1966). For example, DE Bruyn et al. (1971) opened a hole in the bone, through which the myeloid tissue in the marrow cavity could be exposed to be dipped into 
fixation fluid in situ. He claimed that, when the specimens were treated in such a way as to minimize the mechanical damage prior to fixation, the sinus endothelium was kept continuous. CAMPBELL (1972) reported that the same result as DE BRUYN et al. could be obtained by means of vascular perfusion which was expected to provide rapid fixation and to prevent mechanical damage in the tissue which might easily occur when the bone cavity was opened. Using the same method as CAMPBELL's, however, IRINO et al. (1975) reported in their SEM study that numerous large fenestrations occurred on the sinus endothelium. In the present observation under the SEM and TEM after perfusion fixation, we demonstrated that fenestrations not filled by a migrating blood cell were very few in number, in accordance with the results by De Bruyn et al. (1971) and CAmpBell (1972).

We considered that the occurrence of the blood cell-free fenestrations as described under the TEM by immersion fixation was apparently ascribable to inadequate fixation or mechanical damage prior to fixation, whereas the fenestrations obtained by perfusion seemed to be due to detachment of migrating cells during vascular perfusion. Large fenestrations in the sinus are thus presumed to be all associated with a migrating blood cell.

In the same manner as on the large fenestrations, the views on the small pores have been different from author to author. ZAMBONI and PEASE (1961) concluded that they are artifacts, while WEISs (1965) and DE BRUYN et al. (1971) regarded them as true endothelial fenestrations. In the present study, we demonstrated a peculiar grouping of the small pores which was similar to the cribriform area in the sinus wall described by WeIss (1965). We are of the view that it is unlikely that such a regular structure might occur as an artifact. A further discussion on the nature of these pores will be made below.

The second question concerns whether the pathways for migrating blood cells occur intracellularly or intercellularly. On this argument, due to limited occasions to find them in the cross-sectional view of TEM, PEASE $(1955,1965)$ and WEISS (1961) thought that they were situated intercellularly. However, as the result of later, more precise observations on the relationship between the endothelial cell junction and fenestration, it has been generally agreed that the migrating fenestrations are intracellular in location (DE Bruyn, et al., 1966, 1971; CAMPBELL, 1972; TAVAssoli and Crosby, 1973). The "en face" view over the luminal surface of the sinus in the present study readily confirmed that the pathways for erythrocytes and leukocytes always occur through the cytoplasmic attenuation of individual endothelial cells. Moreover, the present study could reveal that the cytoplasmic extensions of megakaryocyte may also penetrate the cytoplasm of the endothelial cell (Fig. 11, 12).

The third discussion point concerns the transient or permanent nature of the endothelial fenestrations, and is closely related to the first problem. The authors who regarded the fenestration to be an artifact unassociated with blood cells believed that every fenestration was only transiently open for blood cell passage and the sinus endothelial lining was otherwise continuous (ZAMBOnI and PeASE, 1961; Hudson and Yoffey, 1966; De Bruyn et al., 1966; W atanabe, 1966; CAmpbell, 1972). On the contrary, some authors believed that fenestrations were present for a longer time and communicated the intrasinal and extrasinal spaces (PEASE, 1955, 1956; WeIss, 1965, 1970).

In the present observation the bone marrow sinus wall appeared continuous 
except for large fenestrations for blood cell migration, if one takes possible dislocation of a few cells under passage into account.

The present study also revealed, in accordance with WEIss (1965), a peculiar figure of small pores arranged in a cribriform area. Although much must be clarified as to their functional role, it is not unreasonable to imagine that a blood cell which starts to migrate might interact with an endothelial lining cell, causing formation of such perforations. As a matter of fact, the grouping pores could be found to occur close to the villous processes projected from a migrating blood cell. We are inclined to suggest that the larger fenestration might be formed by aggregation of these small pores just in the instance of cell passage.

\section{Adventitial cell and basal lamina}

The functional significance of adventitial cells and the nature of their discontinuities remain a matter of dispute. DE BRUYN et al. (1971) thought that the cells were no more than a part of reticulum cells that happened to be located adjacent to the sinus wall and therefore he referred to the cells as parasinusoidal reticulum cells. On the other hand, WEISs (1970) gave a special functional significance to the cells, demonstrating that their extensions were decreased in the bone marrow whose hemopoiesis was stimulated by endotoxin. CAMPBELL (1972) showed contractile element in the adventitial cells and postulated that their extensions might retract when a blood cell crosses through the sinus wall. Mryoshi (1975) also suggested that the extensions of the cells might play a role in regulating the formation and dimension of the endothelial fenestrations. It is not known whether the contractility of bone marrow sinuses may be caused by the endothelium or by adventitial cells.

In the present study, the discontinuities in the adventitial cell layer as seen under the TEM have been revealed to correspond to the spaces between the adjacent extensions of the cell. Cell passage must occur through these spaces and therefore, it may be possible that they might be involved in the regulation of blood cell migration or even in the selection of the mature blood cells which may pass.

Most of the previous authors agreed in that there was no distinctive and complete basal lamina in the bone marrow sinus (ZAMBoni and PeAse, 1961; Weiss, 1965, 1970; CAMPBell, 1972). Only De Bruyn et al. (1971) concluded that bone marrow sinus entirely lacks the basal lamina. The present study confirmed that, as $Z_{\text {AMBONI and }}$ Pease (1961) first described, the basal lamina was discontinuous and completely lacking at the site of the endothelial fenestrations.

\section{Liberation of platelets from megakaryocyte}

Since WRIGHT (1910) concluded by light microscopy that platelets are detached from the cytoplasm of the megakaryocyte, many observations have been made on the mode and site of platelet liberation. Two different mechanisms thus have been considered: 1) as WRIGHT (1910) described the megakaryocyte extends its pseudopodia into the sinus, and platelets are dissociated from its processes; 2) as described especially in the cell culture study by AlBRecht (1957), the cell body of the megakaryocyte is simultaneously cleaved into single platelets.

The first view by WRIGHT (1910) was later confirmed at the TEM level by Keyserlingk and Albrecht (1968) and Huhn and Stich (1969). They showed that a 
megakaryocyte extended its peripheral cytoplasmic processes containing platelets' organella into the sinus, and BEHNKE (1974) demonstrated that the cell processes may form "long slender strips." In their experiments using cultured megakaryocytes, THIÉRY and Bessis (1965) confirmed that "arm-like processes" are extended from the cells. WeIss (1965) suggested that a long strip came off from the megakaryocyte in the same way that a string unwinds from a ball.

The present observation well corresponds to the finding in the early light microscope study by WRIGHT (1910) that the megakaryocyte sends its cytoplasmic processes into the sinus, and moreover it revealed that the processes become constricted periodically. Correlating the present SEM and TEM findings, it seems most reasonable to conclude that a demarcating membrane system occurs inside of each constriction, and single platelets are separated at this site. Our observation, however, is limited and the possible occurrence of the second mechanism of platelet formation: simultaneous fragmentation in the megakaryocyte cell body remains the subject for a future study.

\title{
ラット骨䯣洞と血球の洞壁通過に関する走查・透過型電子顕微鏡による研究
}

\author{
武 藤 正 樹
}

若いラットの骨骾の洞を 走査および透過型電子顕微鏡で観察した.

骨髄の洞壁は，最内層の内皮細胞，最外層の外膜細胞，その間の基底膜の 3 層より成る. 内皮細胞の内面はきわめて平滑で, ところどころに大きさの異なる 2 種類の悹が見られ た. ひとつは比較的大きな空 $(1 \sim 3 \mu \mathrm{m})$ で，血球の遊走にともなって出現するものであ り，他は小さな空 $(0.1 \mu \mathrm{m})$ で，集合して篩板を形成していた．外膜細胞は 透過型電子顕 微鏡の観察では 不連続性を示すが, 走査型電子顕微鏡によれば, この不連続性は外膜細胞 の菲薄な突起の間に生じた孔にほかならなかった。

血管外の造血巣から 洞の中への血球遊出が 数多くみられた.そしてその遊出経路は内 皮細胞間のギャップではなく，細胞内の密を通して生じることが容易に確かめられた。

実質中には大きな細胞質をもつ巨核球が 多数みられた. 巨核球からの血小板放出は次 のようである。 まず，巨核球は その辺縁の細胞質突起を内皮細胞の空を通じて洞内へ延 ばす．この突起は 洞内を延長してゆき，として周期的なくびれを生じる. 血小板はこの くびれに沿ってひきちぎられ，血流中に放出されるのであろう.

遊走血球をともなわない 少数の内皮細胞の空は, 潅流によって 血球がはげおちること で生じたと考えた． 外膜細胞の孔の血球遊走に対する役割が考察された.

\section{References}

Albrecht, M.: Studien zur Thrombozytenbildung an Megakaryocyten in menschlichen Knochenmarkskulturen. Acta haematol. 17: 160-168 (1957).

Behnke, 0. and N. T. Pedersen: Ultrastructual aspects of megakaryocyte, maturation and plate- 
let release. In: (ed. by) M. G. Baldini and S. Ebb: Platelets. New York, Grune and Stratton Inc., 1974. (p. 21-31).

Campbell, F. R.: Ultrastructual studies of transmural migration of blood cells in the bone marrow of rats, mice and guinea pigs. Amer. J. Anat. 135: 521-536 (1972).

De Bruyn, P. P. H., S. Michelson and T. B. Thomas: The migration of blood cells of the bone marrow through the sinusoidal wall. J. Morphol. 133: 417-438 (1971).

De Bruyn, P. P. H., T. B. Thomas and S. Michelson : Fine structure of the vascular components of the guinea pig bone marrow. Anat. Rec. 154: 499 (1966).

Hudson, G. and J. M. Yoffey : The passage of lymphocytes through the sinusoidal endothelium of guinea-pig bone marrow. Proc. Roy. Soc. (Biol.) 165: 486-496 (1966).

Huhn, D.: Die Feinstruktur des Knochenmarks der Ratte bei Anwendung neuerer Aldehydfixationen. Blut 13: 291-304 (1966).

Huhn, D. and W. Stich : Fine structure of blood and bone marrow. München, J. F. Lehmanns Verlag, 1969 (p. 23-24).

Irino, S., T. Ono, K. Watanabe, K. Toyota, J. Uno, N. Takasugi and T. Murakami : Scanning electron microscopic studies on microvascular architecture, sinus wall, and transmural passage of blood cells in the bone marrow by a new method of injection replica and noncoated specimens. In: (ed. by) O. Johari and I. Corvin: Scanning electron microscopy/1975. Chicago, IIT Res. Inst., 1975. (p. 267-274).

Keyserlingk, D. G. und M. Albrecht : Über die Pseudopodien von Megakaryocyten und ihre Bedeutung für die Freisetzung von Thrombocyten. Z. Zellforsch. 89: 320-327 (1968).

Lindblad, G. and N. Björkman : Ultrastructural alterations in sinusoidal endothelium of liver and bone marrow in dogs with experimental hepatitis. Acta pathol. microbiol. scand. 62: 155-164 (1964).

Miyoshi, M. : Scanning electron microscopy of the bone marrow. In: (ed. by) E. Yamada: Proceedings of the Tenth International Congress of Anatomists. Tokyo, Science Council of Japan, 1975. (p. 362).

Murakami, T.: A revised tannin-osmium method for non-coated scanning electron microscope specimens. Arch. histol. jap. 36: 189-193 (1974).

Pease, D. C.: Marrow cells seen with the electron microscope after ultrathin sectioning. Rev. Hématol. 10: 300-313 (1955).

-: An electron microscopic study of red bone marrow. Blood 11: 501-526 (1956).

Tavassoli, M. and W. H. Crosby : Fate of the nucleus of the marrow erythroblast. Sience 179: 912-913 (1973).

Thiéry, J. B. et Bessis, M. : La genèse des plaquettes à partir des mégacaryocytes observés sur la cellule vivate. C. r. Acad. Sci., 242: 290 (1956).

Tokunaga, J., M. Edanaga, T. Fujita and K. Adachi : Freeze cracking of scanning electron microscope specimens. A study of the kidney and spleen. Arch. histol. jap. 37: 165-182 (1974).

Trubowitz, S., A. Broers and R. F. W. Pease: Surface ultrastructure of the human marrow, a brief note. Blood 35: 112-115 (1970).

Watanabe, Y.: An electron microscopic study on the reticuloendothelial system in the bone marrow. Tohoku J. exp. med. 89: 167-176 (1966).

Weiss, L.: An electron microscopic study of the vascular.sinuses of the bone marrow of the rabbit. Bull. Johns Hopkins Hosp. 108: 171-199 (1961).

- : The structure of bone marrow, functional interrelationships of vascular and hematopoietic compartments in experimental hemolytic anemia. J. Morphol. 117: 467-538 (1965).

- : Transmural cellular passage in vascular sinuses of rat bone marrow. Blood 36: 189-208 (1970).

-: The cells and tissues of the immune system. Englewood Cliffs, Prentice-Hall Inc., 1972. p. $(12-24)$. 
Wright, J. H.: The histogensis of the blood platelets. J. Morphol. 21: 263-278 (1910).

Yoffey, J. M., G. Hudson and D. G. Osmond: The lymphocyte in guinea-pig bone marrow. J. Anat. (Lond.) 99: 841-860 (1965).

Zamboni, L. and D. C. Pease : The vascular bed of red bone marrow. J. Ultrastr. Res. 5: 65-85 (1961).

武藤正 樹

下951 新潟市旭町 1

新潟大学医学部

第三解剖学教室
Dr. Masaki Muto

Department of Anatomy

Niigata University School of Medicine

Niigata, 951 Japan 